\title{
Correction to: Treatment Sequencing for Anaplastic Lymphoma Kinase-Rearranged Non-Small-Cell Lung Cancer
}

\author{
Diego Kauffmann-Guerrero ${ }^{1} \cdot$ Kathrin Kahnert ${ }^{1} \cdot$ Rudolf M. Huber $^{1} \mathbb{C}$
}

Published online: 26 May 2021

(c) The Author(s) 2021

\section{Correction to: Drugs (2021) 81:87-100 https://doi.org/10.1007/s40265-020-01445-2}

The Treatment Sequencing for Anaplastic Lymphoma Kinase-Rearranged Non-Small-Cell Lung Cancer, written by Diego Kauffmann-Guerrero, Kathrin Kahnert and Rudolf M. Huber, was originally published electronically on the publisher's internet portal on 23 November 2020 without open access. After publication in volume 81 , issue 1, pages 87-100, with the authors' decision to opt for Open Choice, the copyright of the article changed on 27 May 2021 to (c) The Author(s). This article is licensed under a Creative Commons Attribution-NonCommercial 4.0 International License, which permits any non-commercial use, sharing, adaptation, distribution and reproduction in any medium or format, as long as you give appropriate credit to the original author(s) and the source, provide a link to the Creative Commons licence, and indicate if changes were made. The images or other third party material in this article are included in the article's Creative Commons licence, unless indicated otherwise in a credit line to the material. If material is not included in the article's Creative Commons licence and your intended use is not permitted by statutory regulation or exceeds the permitted use, you will need to obtain permission directly from the copyright holder. To view a copy of this licence, visit http://creativecommons. org/licenses/by-nc/4.0/.

The original article has been corrected.

Open Access This article is licensed under a Creative Commons Attribution-NonCommercial 4.0 International License, which permits any non-commercial use, sharing, adaptation, distribution and reproduction in any medium or format, as long as you give appropriate credit to the original author(s) and the source, provide a link to the Creative Commons licence, and indicate if changes were made. The images or other third party material in this article are included in the article's Creative Commons licence, unless indicated otherwise in a credit line to the material. If material is not included in the article's Creative Commons licence and your intended use is not permitted by statutory regulation or exceeds the permitted use, you will need to obtain permission directly from the copyright holder. To view a copy of this licence, visit http://creativecommons.org/licenses/by-nc/4.0/.

The original article can be found online at https://doi.org/10.1007/ s40265-020-01445-2.

Rudolf M. Huber

huber@med.uni-muenchen.de

1 Division of Respiratory Medicine and Thoracic Oncology, Department of Internal Medicine V and Thoracic Oncology Centre Munich (TOM), Hospital of the University of Munich (LMU), Comprehensive Pneumology Center (CPC-M),

Member of the German Center for Lung Research (DZL), Medizinische Klinik, Ziemssenstraße 1, 80336 Munich, Germany 